\title{
Czynniki wpływające na stan odżywienia pacjentów leczonych z powodu niedokrwistości aplastycznej i z niedoboru żelaza
}

\author{
Factors influencing nutritional status of patients \\ treated due to aplastic and iron deficiency anemia
}

\section{Streszczenie}

Wstęp: Zaburzenia stanu odżywienia stanowią istotny problem medyczny i społeczny. Na całym świecie $14 \%$ ludzi jest niedożywionych. Pacjenci z anemią charakteryzują się objawami, które mają znaczący wpływ na odżywianie. Przede wszystkim są to zmniejszony apetyt oraz zaburzone odczuwanie smaku. Dodatkowo działania niepożadane zastosowanego leczenia — nudności i wymioty, owrzodzenia jamy ustnej i przewodu pokarmowego oraz bolesne pęknięcia kącików ust — powodują trudności w przyjmowaniu posiłków oraz problemy z prawidłowym przyswajaniem składników odżywczych. Problemy z odżywianiem powodują wiele zaburzeń w organizmie. Z uwagi na powyższe pacjent z niedokrwistością powinien być wnikliwie obserwowany w kierunku zaburzeń odżywiania.

Celem pracy była ocena stanu odżywienia chorych z rozpoznaniem niedokrwistości i identyfikacja czynników mających wpływ na stan odżywienia pacjentów leczonych z powodu niedokrwistości.

Materiał i metody: W badaniu brało udział 108 chorych (58 kobiet, średnia wieku 52,7 lat) leczonych z powodu niedokrwistości z niedoboru żelaza (54 osoby) i niedokrwistości aplastycznej (54 osoby). Do oceny stanu odżywienia zastosowano Mini Nutritional Assessment (MNA). Dane socjokliniczne i socjodemograficzne pochodziły z dokumentacji medycznej. Pacjentów podzielono na trzy grupy w zależności od stanu odżywienia: grupa I - prawidłowy stan odżywienia ( $n=52$; MNA: 24-30), grupa II — zagrożenie niedożywieniem ( $n=42$; MNA: 17-23), grupa III - niedożywienie $(n=14$; MNA < 17).

Wyniki. Prawidłowy stan odżywienia wykazywało 48,15\% ankietowanych, 38,89\% było zagrożonych niedożywieniem, a 12,96\% niedożywionych. Pacjenci z wykształceniem wyższym byli lepiej odżywieni od chorych $z$ wykształceniem podstawowym $(23,15$ vs. 19,$78 ; p=0,043)$, a osoby czynne zawodowo były lepiej odżywione od emerytów i rencistów $(24,77$ vs. 20,8; $p<0,001)$. Stan odżywienia nie zależał w sposób istotny od płci, stanu cywilnego i miejsca zamieszkania $(p>0,05)$. W analizie korelacji wpływu wybranych zmiennych na stan odżywienia starszy wiek oraz brak apetytu wiązały się z gorszym stanem odżywienia (odpowiednio: współczynnik korelacji $-0,26 ; p=0,007$ vs. współczynnik korelacji 0,743; $\mathrm{p}<0,05)$. Wśród czynników socjoklinicznych negatywny wpływ na stan odżywienia miała obecność chorób przewlekłych $(21,48$ vs. 23,84; $p=0,002)$, liczba hospitalizacji powyżej 2 w ciągu ostatniego roku $(26,59$ vs. 21,$2 ; p<0,001)$ oraz chemioterapia $(24,23$ vs. 19,64; $p<0,001)$. Obecność owrzodzeń jamy

Adres do korespondencji:

Natalia Alicja Świątoniowska

Zakład Pielęgniarstwa Internistycznego,

Uniwersytet Medyczny im. Piastów Śląskich we Wrocławiu

e-mail: natalia.swiat@o2.pl 
ustnej wiązała się z gorszym stanem odżywienia $(23,02$ vs. 19,69; $p=0,013)$, podobnie jak występowanie nudności i wymiotów $(23,93$ vs. 18,88; $p<0,001)$ i wyłysienia $(24,04$ vs. 19,$64 ; p<0,001)$. W analizie wieloczynnikowej niezależnym predyktorem stanu odżywienia był apetyt - im lepszy apetyt, tym lepszy stan odżywienia $(\beta=0,554 ; p<0,001)$.

Wnioski: Chorzy z rozpoznaniem niedokrwistości aplastycznej wykazują gorszy stan odżywienia w porównaniu z pacjentami z rozpoznaniem niedokrwistości z niedoboru żelaza. Niezależny czynnik predykcyjny stanu odżywienia pacjentów z niedokrwistością aplastyczną i z niedoboru żelaza stanowi apetyt. Stan odżywienia zależy od wieku, wykształcenia, aktywności zawodowej, chorób współistniejących, nudności, wymiotów, owrzodzeń jamy ustnej, chemioterapii i liczby hospitalizacji.

Palliat Med Pract 2019; 13, 1: 1-10

Słowa kluczowe: stan odżywienia, niedokrwistość, czynniki wpływające na stan odżywienia

\section{Abstract}

Introduction: Disorders of nutritional status are a significant medical and social problem. $14 \%$ of people are undernourished worldwide. Patients with anemia are characterized by symptoms that have a significant effect on nutrition. First of all, they are reduced appetite and disturbed taste perception. In addition, the side effects of the treatment - nausea and vomiting, mouth ulcers and gastrointestinal ulcers and painful cracks in the corners of the mouth - cause difficulties in taking meals and problems with the proper absorption of nutrients. Eating problems cause a number of disorders in the body. In view of the above, an anemic patient should be closely monitored for eating disorders. The aim of the study was to assess the nutritional status of patients with anemia and identify factors affecting the nutritional status of patients treated for anemia.

Material and methods: 108 patients (58 women, mean age of the respondents 52.7 years) treated for iron deficiency anemia (54 patients) and aplastic anemia (54 patients). The study used the MNA (Mini Nutritional Assessment) to assess nutritional status. The socio-clinical and sociodemographic data were taken from the medical records. Patients were divided into three groups depending on the nutritional status: group I - normal nutritional status ( $n=52$, MNA: 24-30), group II - risk of malnutrition ( $n=42$, MNA: $17-23)$, group III - malnutrition ( $n=14$; MNA < 17).

Results: $48.15 \%$ of the respondents had a healthy nutritional status, $38.89 \%$ were at risk of malnutrition and $12.96 \%$ of malnourished people. Patients with higher education were better nourished than patients with primary education ( 23.15 vs. $19.78, p=0.043)$, and professionally active people were better nourished than pensioners $(24.77$ vs. 20.8; $p<0.001)$. Nutrition status did not depend significantly on sex, marital status and place of residence $(p>0.05)$. In the analysis of the correlation of the impact of selected variables on the nutritional status, older age and lack of appetite were associated with a worse state of nutrition (correlation coefficient $-0.26, p=0.007$ vs. correlation coefficient of $0.743, p<0.05$ ). Among the socio-clinical factors, the negative effect on the nutritional status was the presence of chronic diseases (21.48 vs. 23.84, $\mathrm{p}=0.002)$, the number of hospitalizations over 2 in the last year (26.59 vs. 21.2, $p<0.001)$ and chemotherapy ( 24.23 vs. $19.64, p<0.001)$. The presence of oral ulcers was associated with a worse state of nutrition ( 23.02 vs. $19.69, p=0.013)$, as well as the occurrence of nausea and vomiting ( 23.93 vs. $18.88, p<0.001)$ and baldness $(24,04$ vs. $19.64, p<0.001)$. In multivariate analysis, the independent predictor of nutritional status was appetite - the better the appetite, the better the nutritional status $(\beta=0.554, p<0.001)$.

Conclusions. Patients with aplastic anemia have an inferior nutritional status compared to patients with iron deficiency anemia. The amount of hospitalization affects the nutritional status. An independent predictor of the nutritional status of patients with aplastic anemia and iron deficiency is appetite. Nutritional status depends on age, education, occupational activity, comorbidities, nausea, vomiting, mouth ulcers, chemotherapy and number of hospitalizations.

Palliat Med Pract 2019; 13, 1: 1-10

Key words: nutritional status, anemia, factors affecting nutritional status

\section{Wstęp}

Zgodnie z definicją Światowej Organizacji Zdrowia (WHO, World Health Organization) niedożywienie określane jest, jako brak równowagi pomiędzy zapotrzebowaniem na składniki pokarmowe i energię a podażą, której zaspokojenie pozwala na wzrost, podtrzymanie czynności życiowych i pełnienie określonych funkcji [1]. Zaburzenia stanu odżywienia stanowią istotny problem medyczny i społeczny. Na całym świecie 14\% ludzi jest niedożywionych, w Europie odsetek osób niedożywionych wynosi $3 \%$, a w populacji ludzi zdrowych w Polsce 0,8\% [2]. Zaburzenia odżywiania dotyczą 30-70\% pacjentów 
hospitalizowanych, z czego $80 \%$ to chorzy na nowotwory.

Zaburzenia odżywiania powodują pogorszenie wyników leczenia, ale także przedłużają okres hospitalizacji, a co za tym idzie, zwiększają koszty leczenia [3]. Wśród przyczyn niedożywienia wymieniane są nieprawidłowo skomponowana, niskokaloryczna dieta, stosowanie leków, choroby przewodu pokarmowego, rany i oparzenia [2]. Niedożywienie wywołuje wiele zaburzeń w organizmie: osłabienie siły mięśniowej i kurczliwości serca, pogorszenie sprawności psychomotorycznej i odporności organizmu, ponadto występują zaburzenia trawienia i wchłaniania pokarmu, gospodarki elektrolitowej, wtórnie wzrasta liczba zakażeń, utrudnione gojenie ran i w konsekwencji wzrost liczby zgonów [4].

$\mathrm{U}$ chorych z rozpoznaniem niedokrwistości występują objawy, które znacząco wpływają na stan odżywienia, głównie gorszy apetyt i zaburzone odczuwanie smaku, działania niepożądane zastosowanego leczenia - nudności i wymioty, owrzodzenia jamy ustnej i przewodu pokarmowego oraz bolesne pęknięcia kącików ust, które powodują trudności w przyjmowaniu posiłków i przyswajaniem składników odżywczych. W konsekwencji pacjent jest zniechęcony do przyjmowania pokarmu i zagrożony niedożywaniem.

Zagadnienia wpływu odżywiana na przebieg choroby i jakość życia pacjentów stanowią coraz częściej obszar zainteresowania wielu badaczy i chociaż wzrasta liczba chorych niedożywionych i zagrożonych niedożywieniem, niewiele badań dotyczy stanu odżywienia pacjentów z rozpoznaniem niedokrwistości. U chorych z niedokrwistością z niedoboru żelaza błędy żywieniowe (m.in. zbyt mała podaż żelaza z pokarmem) wpływają na wystąpienie niedokrwistości i przebieg leczenia, natomiast u wielu chorych z niedokrwistością aplastyczną występuje zagrożenie niedożywieniem lub niedożywienie na skutek przebiegu choroby bądź zastosowanego leczenia.

Celem pracy była ocena stanu odżywienia chorych z rozpoznaniem niedokrwistości i identyfikacja czynników wpływających na stan odżywienia pacjentów leczonych z powodu niedokrwistości.

\section{Materiał i metody}

W badaniu brało udział 108 chorych (58 kobiet, średni wiek 52,7 lat) z rozpoznaniem niedokrwistości z niedoboru żelaza (54 osoby) i niedokrwistości aplastycznej (54 osoby), w okresie od listopada 2016 do marca 2017 roku. Kryterium włączenia do badania stanowiło rozpoznanie niedokrwistości na podstawie objawów klinicznych i parametrów biochemicznych oraz świadoma, pisemna zgoda na udział w bada- niu. Pacjenci zakwalifikowani do badania byli leczeni w poradni hematologicznej, na Oddziale Dziennym Onkologii Klinicznej i na Oddziale Onkologii Klinicznej Uniwersyteckiego Szpitala Klinicznego we Wrocławiu. Do oceny stanu odżywienia zastosowano Mini Nutritional Assessment (MNA), dane socjokliniczne i socjodemograficzne pochodziły z dokumentacji medycznej.

Mini Nutritional Assessment służy do oceny wskaźnika niedożywienia. Maksymalnie pacjent może uzyskać 30 punktów. Wynik w zakresie 24-30 punktów stanowi o prawidłowym stanie odżywienia, 17-23 punktów świadczy o zagrożeniu niedożywieniem, a poniżej 17 punktów o niedożywieniu. Kwestionariusz składa się dwóch części: badanie przesiewowe i ocena pacjenta. Badanie przesiewowe obejmuje sześć zagadnień: ograniczenie w spożywaniu posiłków w ostatnich 3 miesiącach, utratę masy ciała w ostatnich 3 miesiącach, możliwości poruszania się, przebytą ciężką chorobę lub stres psychologiczny w ostatnich 3 miesiącach, zaburzenia neuropsychologiczne i wskaźnik masy ciała (BMI, body mass index). Kwestionariusz dotyczy również samodzielnego mieszkania pacjenta we własnym domu, przyjmowanych leków na receptę, odleżyn lub owrzodzeń skóry, liczby spożywanych posiłków, spożycia białka wraz z posiłkami, spożycia owoców i warzyw dziennie, ilości wypijanych napojów dziennie, samodzielności spożywania posiłków, ocenę własnego stanu zdrowia w porównaniu z rówieśnikami. Ocenie podlega również obwód ramienia i łydki [5].

\section{Wyniki}

Charakterystyka socjodemograficzna i kliniczna chorych w zależności od stanu odżywienia. Według MNA 48,15\% chorych cechował prawidłowy stan odżywienia, 38,89\% pacjentów było zagrożonych niedożywieniem, a 12,96\% chorych było niedożywionych. Problemów z apetytem nie zgłaszało 66,67\% pacjentów, natomiast 33,33\% wymagało obserwacji. W tabeli 1 przedstawiono charakterystykę socjodemograficzną pacjentów w zależności od stanu odżywienia. Chorzy zagrożeni niedożywieniem i niedożywieni to głównie kobiety $(57,14 \%$ vs. 59,52\%), osoby w związku $(57,14 \%$ vs. 52,38\%), mieszkające w mieście (64,29\% vs. 59,52\%). Prawidłowy stan odżywienia osiągali częściej mężczyźni (51,92\%), będący w związku $(61,54 \%)$ i mieszkańcy miast $(59,62 \%)$.

Badane grupy istotnie różniły się poziomem wykształcenia $(p=0,02)$ i aktywnością zawodową ( $p<0,001)$. Najlepiej wykształceni byli pacjenci z prawidłowym stanem odżywienia (46,15\%), 57,69\% aktywnych zawodowo pacjentów odżywiało się prawidłowo. Najgorzej odżywieni byli bezrobotni — 50\% 
Tabela 1. Charakterystyka socjodemograficzna z podziałem na stan odżywienia

\begin{tabular}{|c|c|c|c|c|c|c|c|c|}
\hline \multirow[t]{2}{*}{ Cecha } & & \multicolumn{2}{|c|}{$\begin{array}{l}\text { Niedożywienie } \\
\quad(n=14)\end{array}$} & \multicolumn{2}{|c|}{$\begin{array}{l}\text { Zagrożenie niedoży- } \\
\text { wieniem }(n=42)\end{array}$} & \multicolumn{2}{|c|}{$\begin{array}{c}\text { Prawidłowy stan } \\
\text { odżywienia }(n=52)\end{array}$} & \multirow[t]{2}{*}{$\mathbf{p}$} \\
\hline & & $\mathbf{n}$ & $\%$ & $\mathbf{n}$ & $\%$ & $\mathbf{n}$ & $\%$ & \\
\hline \multirow[t]{2}{*}{ Płeć } & Mężczyzna & 6 & $42,86 \%$ & 17 & $40,48 \%$ & 27 & $51,92 \%$ & \multirow{2}{*}{0,522} \\
\hline & Kobieta & 8 & $57,14 \%$ & 25 & $59,52 \%$ & 25 & $48,08 \%$ & \\
\hline \multirow[t]{2}{*}{ Stan cywilny } & W związku & 8 & $57,14 \%$ & 22 & $52,38 \%$ & 32 & $61,54 \%$ & \multirow{2}{*}{0,671} \\
\hline & Wolna/y & 6 & $42,86 \%$ & 20 & $47,62 \%$ & 20 & $38,46 \%$ & \\
\hline \multirow{2}{*}{$\begin{array}{l}\text { Miejsce } \\
\text { zamieszkania }\end{array}$} & Miasto & 9 & $64,29 \%$ & 25 & $59,52 \%$ & 31 & $59,62 \%$ & \multirow{2}{*}{0,945} \\
\hline & Wieś & 5 & $35,71 \%$ & 17 & $40,48 \%$ & 21 & $40,38 \%$ & \\
\hline \multirow[t]{4}{*}{ Wykształcenie } & Podstawowe & 4 & $28,57 \%$ & 9 & $21,43 \%$ & 5 & $9,62 \%$ & \multirow{4}{*}{0,02} \\
\hline & Zawodowe & 0 & $0,00 \%$ & 11 & $26,19 \%$ & 8 & $15,38 \%$ & \\
\hline & Średnie & 3 & $21,43 \%$ & 14 & $33,33 \%$ & 15 & $28,85 \%$ & \\
\hline & Wyższe & 7 & $50,00 \%$ & 8 & $19,05 \%$ & 24 & $46,15 \%$ & \\
\hline \multirow[t]{4}{*}{$\begin{array}{l}\text { Aktywność } \\
\text { zawodowa }\end{array}$} & $\begin{array}{l}\text { Czynny/a } \\
\text { zawodowo }\end{array}$ & 1 & $7,14 \%$ & 14 & $33,33 \%$ & 30 & $57,69 \%$ & \multirow{4}{*}{$\begin{array}{c}< \\
0,001\end{array}$} \\
\hline & Bezrobotny/a & 7 & $50,00 \%$ & 4 & $9,52 \%$ & 11 & $21,15 \%$ & \\
\hline & Emeryt/ka & 5 & $35,71 \%$ & 20 & $47,62 \%$ & 11 & $21,15 \%$ & \\
\hline & Rencista/ka & 1 & $7,14 \%$ & 4 & $9,52 \%$ & 0 & $0,00 \%$ & \\
\hline
\end{tabular}

Tabela 2. Charakterystyka wieku z podziałem na stan odżywienia

\begin{tabular}{|c|c|c|c|c|c|c|c|}
\hline \multirow{2}{*}{ Cecha } & \multicolumn{2}{|c|}{$\begin{array}{c}\text { Niedożywienie } \\
(n=14) \\
\end{array}$} & \multicolumn{2}{|c|}{$\begin{array}{l}\text { Zagrożenie niedożywieniem } \\
\qquad(\mathrm{n}=42)\end{array}$} & \multicolumn{2}{|c|}{$\begin{array}{l}\text { Prawidłowy stan odżywienia } \\
\qquad(\mathrm{n}=52)\end{array}$} & \multirow{2}{*}{$\mathbf{p}$} \\
\hline & $\begin{array}{l}\text { Średnia } \\
\text { (SD) }\end{array}$ & $\begin{array}{c}\text { Mediana } \\
\text { (kwartyle) }\end{array}$ & $\begin{array}{l}\text { Średnia } \\
\text { (SD) }\end{array}$ & $\begin{array}{c}\text { Mediana } \\
\text { (kwartyle) }\end{array}$ & $\begin{array}{l}\text { Średnia } \\
\text { (SD) }\end{array}$ & $\begin{array}{c}\text { Mediana } \\
\text { (kwartyle) }\end{array}$ & \\
\hline $\begin{array}{l}\text { Wiek } \\
\text { (lata) }\end{array}$ & $52,2 \pm 22,7$ & $43(35-68,8)$ & $59,5 \pm 18$ & $60(48,2-74,2)$ & $47,3 \pm 16,2$ & $45(33,8-58,8)$ & 0,237 \\
\hline
\end{tabular}

SD (standard deviation) — odchylenie standardowe

niedożywionych, a w grupie emerytów 47,62\% zagrażało niedożywienie.

Prawidłowy stan odżywienia częściej wykazywały osoby młodsze $(47,3 \pm 16,2)$. Nie zaobserwowano istotnej statystycznie zależności pomiędzy wiekiem badanych a stanem odżywienia ( $p>0,05)$ (tab. 2).

Stan odżywienia pacjentów zależał od wybranych czynników klinicznych (tab. 3). Częściej zagrożeni niedożywieniem byli pacjenci z chorobami przewlekłymi, w porównaniu z chorującymi wyłącznie na niedokrwistość $(78,57 \%$ vs. $21,43 \%$; $p<0,001)$, hospitalizowani częściej w okresie jednego roku ( $p<0,001$ ), z niedokrwistością aplastyczną, w porównaniu z niedokrwistością z niedoboru żelaza (73,81\% vs. 26,19\%; $\mathrm{p}<0,001)$ i leczeni chemicznie, w porównaniu z leczonymi innymi metodami $(47,62 \%$ vs. $4,76 \%$ vs. $11,90 \%$; $\mathrm{p}<0,001)$.

Osoby z prawidłowym stanem odżywienia cechował brak chorób współistniejących (65,38\%, $\mathrm{p}<0,001)$, brak hospitalizacji w okresie ostatniego roku $(63,46 \%, p<0,001)$, byli leczeni z powodu niedokrwistości z niedoboru żelaza (76,92\%; $p<0,001)$. Pacjenci bez zaburzeń w zakresie odżywiania, w porównaniu z chorymi ze stanem odżywienia zaburzonym lub będących w grupie ryzyka, istotnie rzadziej zgłaszali nudności i wymioty $(9,62 \%$ vs. $57,14 \%$ vs. $35,71 \% ; p<0,001)$, tysienie $(13,46 \%$ vs. $50 \%$ vs. $50 \% ; p<0,001)$ i owrzodzenia jamy ustnej $(5,77 \%$ vs. $28,57 \%$ vs. $14,29 \% ; p=0,048)$.

Pacjenci ze stanem odżywienia zaburzonym najczęściej byli leczeni chemicznie $(71,43 \%, p<0,001)$, zgłaszali więcej objawów niepożądanych leczenia, częściej rozpoznano niedokrwistość aplastyczną, charakteryzowali się brakiem chorób towarzyszących i najczęściej byli hospitalizowani przynajmniej 5 razy częściej w okresie ostatniego roku.

W tabeli 4 przedstawiono wyniki badań klinicznych pacjentów z podziałem na stan odżywienia. Pacjentów 
Tabela 3. Charakterystyka kliniczna w zależności od stanu odżywienia

\begin{tabular}{|c|c|c|c|c|c|c|c|c|}
\hline \multirow[t]{2}{*}{ Cecha } & & \multicolumn{2}{|c|}{$\begin{array}{l}\text { Niedożywienie } \\
\quad(n=14)\end{array}$} & \multicolumn{2}{|c|}{$\begin{array}{l}\text { Zagrożenie niedoży- } \\
\text { wieniem }(n=42)\end{array}$} & \multicolumn{2}{|c|}{$\begin{array}{c}\text { Prawidłowy stan } \\
\text { odżywienia }(n=52)\end{array}$} & \multirow[t]{2}{*}{ p } \\
\hline & & $n$ & $\%$ & $n$ & $\%$ & $n$ & $\%$ & \\
\hline \multirow{2}{*}{$\begin{array}{l}\text { Choroby } \\
\text { przewlekłe }\end{array}$} & Nie & 9 & $64,29 \%$ & 9 & $21,43 \%$ & 34 & $65,38 \%$ & \multirow{2}{*}{$<0,001$} \\
\hline & Tak & 5 & $35,71 \%$ & 33 & $78,57 \%$ & 18 & $34,62 \%$ & \\
\hline \multirow{6}{*}{$\begin{array}{l}\text { Hospitalizacje } \\
\text { w okresie } \\
\text { ostatniego } \\
\text { roku }\end{array}$} & 0 razy & 0 & $0,00 \%$ & 5 & $11,90 \%$ & 33 & $63,46 \%$ & \multirow{6}{*}{$<0,001$} \\
\hline & Raz & 1 & $7,14 \%$ & 4 & $9,52 \%$ & 5 & $9,62 \%$ & \\
\hline & 2 razy & 2 & $14,29 \%$ & 9 & $21,43 \%$ & 4 & $7,69 \%$ & \\
\hline & 3 razy & 4 & $28,57 \%$ & 7 & $16,67 \%$ & 2 & $3,85 \%$ & \\
\hline & 4 razy & 2 & $14,29 \%$ & 11 & $26,19 \%$ & 3 & $5,77 \%$ & \\
\hline & 5 razy i więcej & 5 & $35,71 \%$ & 6 & $14,29 \%$ & 5 & $9,62 \%$ & \\
\hline \multirow[t]{2}{*}{$\begin{array}{l}\text { Rodzaj nie- } \\
\text { dokrwistości }\end{array}$} & $\begin{array}{l}\text { Z niedoboru } \\
\text { żelaza }\end{array}$ & 3 & $21,43 \%$ & 11 & $26,19 \%$ & 40 & $76,92 \%$ & \multirow[t]{2}{*}{$<0,001$} \\
\hline & Aplastyczna & 11 & $78,57 \%$ & 31 & $73,81 \%$ & 12 & $23,08 \%$ & \\
\hline \multirow{3}{*}{$\begin{array}{l}\text { Środki farma- } \\
\text { kologiczne }\end{array}$} & Nie & 0 & $0,00 \%$ & 2 & $4,76 \%$ & 1 & $1,92 \%$ & 0,697 \\
\hline & Tak & 14 & $100,00 \%$ & 40 & $95,24 \%$ & 49 & $94,23 \%$ & \\
\hline & Brak danych & 0 & $0,00 \%$ & 0 & $0,00 \%$ & 2 & $3,85 \%$ & \\
\hline \multirow[t]{8}{*}{$\begin{array}{l}\text { Powikłania } \\
\text { po leczeniu }\end{array}$} & $\begin{array}{l}\text { Nudności, } \\
\text { wymioty }\end{array}$ & 8 & $57,14 \%$ & 15 & $35,71 \%$ & 5 & $9,62 \%$ & $<0,001$ \\
\hline & Wyłysienie & 7 & $50,00 \%$ & 21 & $50,00 \%$ & 7 & $13,46 \%$ & $<0,001$ \\
\hline & $\begin{array}{l}\text { Owrzodzenia } \\
\text { jamy ustnej }\end{array}$ & 4 & $28,57 \%$ & 6 & $14,29 \%$ & 3 & $5,77 \%$ & 0,048 \\
\hline & $\begin{array}{l}\text { Owrzodzenia } \\
\text { przewodu } \\
\text { pokarmowego }\end{array}$ & 4 & $28,57 \%$ & 4 & $9,52 \%$ & 0 & $0,00 \%$ & 0,001 \\
\hline & Kardiotoksyczność & 1 & $7,14 \%$ & 1 & $2,38 \%$ & 0 & $0,00 \%$ & 0,118 \\
\hline & Wynaczynienie & 0 & $0,00 \%$ & 0 & $0,00 \%$ & 1 & $1,92 \%$ & 1 \\
\hline & Mielotoksyczność & 0 & $0,00 \%$ & 0 & $0,00 \%$ & 1 & $1,92 \%$ & 1 \\
\hline & Inne & 0 & $0,00 \%$ & 4 & $9,52 \%$ & 1 & $1,92 \%$ & 0,256 \\
\hline \multirow[t]{3}{*}{ Leczenie } & Chemioterapia & 10 & $71,43 \%$ & 20 & $47,62 \%$ & 8 & $15,38 \%$ & $<0,001$ \\
\hline & $\begin{array}{l}\text { Leczenie } \\
\text { paliatywne }\end{array}$ & 1 & $7,14 \%$ & 2 & $4,76 \%$ & 0 & $0,00 \%$ & 0,159 \\
\hline & Radioterapia & 2 & $14,29 \%$ & 5 & $11,90 \%$ & 0 & $0,00 \%$ & 0,013 \\
\hline
\end{tabular}

prawidłowo odżywionych cechowały istotnie wyższe wartości hematokrytu, w porównaniu z osobami z wynikiem zaburzonym i z grupy ryzyka (31,8\% vs. $26,9 \%$ vs. 29,4\%). Najniższe średnie stężenie erytrocytów 3,2 $\mathrm{mln} / \mu \mathrm{l}$ zaobserwowano u pacjentów niedożywionych, a najwyższy u osób prawidłowo odżywionych $(3,9 \mathrm{mln} / \mu \mathrm{l} ; \mathrm{p}<0,001)$. Pacjenci prawidłowo odżywieni wykazywali istotnie niższe stężęnie MCV (średnia objętość krwinki czerwonej), w porównaniu z pacjentami zagrożonymi niedożywieniem $(78,1 \mathrm{fl}$ vs. 83,7 fl; $\mathrm{p}=0,004)$. Wartości MCH (średnia masa hemoglobiny w erytrocytach) i MCHC (średnie stężenie hemoglobiny w erytrocycie) nie różniły się w zależności od grup badanych w sposób istotny.

\section{Czynniki wpływające na stan odżywienia}

Analiza statystyczna wykazała zależności pomiędzy zmiennymi socjodemograficznymi a liczbą punktów MNA (tab. 5). Stan odżywienia zależy od wykształcenia i aktywności zawodowej; pacjenci z wykształceniem wyższym byli lepiej odżywieni w porównaniu z chorymi z wykształceniem podstawowym $(23,15$ vs. 19,$78 ; p=0,043)$. Osoby czynne zawodowo były lepiej odżywione od emerytów i rencistów $(24,77$ vs. 20,$8 ; p<0,001)$, stan odżywienia nie zależy od płci, stanu cywilnego i miejsca zamieszkania ( $p>0,05)$. 
Tabela 4. Wyniki badań klinicznych z podziałem na stan odżywienia

\begin{tabular}{|c|c|c|c|c|c|c|c|}
\hline \multirow[t]{2}{*}{ Cecha } & \multicolumn{2}{|c|}{$\begin{array}{l}\text { Niedożywienie } \\
\quad(n=14)\end{array}$} & \multicolumn{2}{|c|}{$\begin{array}{l}\text { Zagrożenie niedożywieniem } \\
\qquad(n=42)\end{array}$} & \multicolumn{2}{|c|}{$\begin{array}{l}\text { Prawidłowy stan } \\
\text { odżywienia }(n=52)\end{array}$} & \multirow[t]{2}{*}{$\mathbf{p}$} \\
\hline & $\begin{array}{l}\text { Średnia } \\
\text { (SD) }\end{array}$ & $\begin{array}{c}\text { Mediana } \\
\text { (kwartyle) }\end{array}$ & $\begin{array}{l}\text { Średnia } \\
\text { (SD) }\end{array}$ & $\begin{array}{c}\text { Mediana } \\
\text { (kwartyle) }\end{array}$ & $\begin{array}{l}\text { Średnia } \\
\text { (SD) }\end{array}$ & $\begin{array}{c}\text { Mediana } \\
\text { (kwartyle) }\end{array}$ & \\
\hline $\begin{array}{l}\text { Hematokryt } \\
(\%)\end{array}$ & $26,9(5,6)$ & $\begin{array}{c}26 \\
(23,3-28,8)\end{array}$ & $\begin{array}{l}29,4 \\
(5,3)\end{array}$ & $\begin{array}{c}29,1 \\
(26,3-33,3)\end{array}$ & $\begin{array}{l}31,8 \\
(5,4)\end{array}$ & $\begin{array}{c}31,9 \\
(29-36)\end{array}$ & 0,002 \\
\hline $\begin{array}{l}\text { Erytrocyty } \\
{[\mathrm{mln} / \mu \mathrm{l}]}\end{array}$ & $\begin{array}{c}3,2 \\
(0,8)\end{array}$ & $\begin{array}{c}2,8 \\
(2,7-3,4)\end{array}$ & $\begin{array}{c}3,4 \\
(0,7)\end{array}$ & $\begin{array}{c}3,3 \\
(3-3,9)\end{array}$ & $\begin{array}{c}3,9 \\
(0,7)\end{array}$ & $\begin{array}{c}3,7 \\
(3,3-4,3)\end{array}$ & 0,001 \\
\hline $\operatorname{MCV}[\mathrm{fl}]$ & $82,3(11,2)$ & $\begin{array}{c}81,5 \\
(76,9-86,8)\end{array}$ & $\begin{array}{l}83,7 \\
(8,8)\end{array}$ & $\begin{array}{c}84,6 \\
(80-88,5)\end{array}$ & $\begin{array}{l}78,1 \\
(7,4)\end{array}$ & $\begin{array}{c}78 \\
(72-82,4)\end{array}$ & 0,004 \\
\hline $\mathrm{MCH}[\mathrm{pg}]$ & $27,5(4,2)$ & $\begin{array}{c}28,1 \\
(25,4-29,3)\end{array}$ & $\begin{array}{l}28,2 \\
(4,1)\end{array}$ & $\begin{array}{c}29 \\
(26-30)\end{array}$ & $\begin{array}{l}26,4 \\
(3,6)\end{array}$ & $\begin{array}{c}26,8 \\
(23,2-28,8)\end{array}$ & 0,082 \\
\hline $\mathrm{MCHC}[\mathrm{g} / \mathrm{dl}]$ & $31,6(4,2)$ & $\begin{array}{c}33,2 \\
(30,9-34,5)\end{array}$ & $\begin{array}{c}33 \\
(2,6)\end{array}$ & $\begin{array}{c}33,1 \\
(31,5-34,6)\end{array}$ & $\begin{array}{c}32,6 \\
(3)\end{array}$ & $\begin{array}{c}33 \\
(31-34,9)\end{array}$ & 0,728 \\
\hline
\end{tabular}

SD (standard deviation) — odchylenie standardowe

Tabela 5. Charakterystyka poziomu stanu odżywienia w zależności od wybranych zmiennych

\begin{tabular}{|c|c|c|c|c|c|}
\hline \multirow{2}{*}{ Cecha } & \multicolumn{4}{|c|}{ MNA (punkty) } & \multirow{2}{*}{$\mathbf{p}$} \\
\hline & $\mathbf{N}$ & Średnia & SD & Mediana & \\
\hline \multicolumn{5}{|l|}{ Płeć } & \multirow{3}{*}{0,503} \\
\hline Mężczyzna & 50 & 22,86 & 4,91 & 24,25 & \\
\hline Kobieta & 58 & 22,41 & 4,76 & 22,75 & \\
\hline \multicolumn{5}{|l|}{ Stan cywilny: } & \multirow{3}{*}{0,379} \\
\hline w związku & 62 & 22,89 & 4,9 & 24,25 & \\
\hline wolna/y & 46 & 22,25 & 4,72 & 22,5 & \\
\hline \multicolumn{5}{|l|}{ Miejsce zamieszkania: } & \multirow{3}{*}{0,364} \\
\hline Miasto & 65 & 22,29 & 4,85 & 23 & \\
\hline Wieś & 43 & 23,1 & 4,77 & 23,5 & \\
\hline \multicolumn{5}{|l|}{ Wykształcenie: } & \multirow{5}{*}{0,043} \\
\hline Podstawowe & 18 & 19,78 & 4,58 & 19,5 & \\
\hline Zawodowe & 19 & 23,45 & 3,62 & 23 & \\
\hline Średnie & 32 & 23,06 & 4,35 & 23,5 & \\
\hline Wyższe & 39 & 23,15 & 5,44 & 25 & \\
\hline \multicolumn{5}{|l|}{ Aktywność zawodowa: } & \multirow{4}{*}{$<0,001$} \\
\hline czynny/a zawodowo & 45 & 24,77 & 3,32 & 25,5 & \\
\hline bezrobotny/a & 22 & 21,59 & 5,95 & 23 & \\
\hline emeryt/ka, rencista/ka & 41 & 20,8 & 4,7 & 20,5 & \\
\hline
\end{tabular}

MNA - Mini Nutritional Assessment; SD (standard deviation) - odchylenie standardowe

Wiek i apetyt istotnie wpływały na stan odżywienia badanych ( $p<0,001$ ) (tab. 6). Im starszy wiek, tym gorszy stan odżywienia (współczynnik korelacji-0,26; $\mathrm{p}=0,007)$, im większy apetyt, tym lepszy stan odżywienia (współczynnik korelacji 0,743; $p<0,05$ ).

Spośród czynników socjoklinicznych wpływ na stan odżywienia wykazywała obecność chorób przewlekłych, liczba hospitalizacji w okresie ostatniego roku, występowanie działań niepożądanych leczenia i chemioterapia (tab. 7). Pacjenci przewlekle chorzy byli gorzej odżywieni w porównaniu z pacjentami bez takich chorób $(21,48$ vs. 23,84; $p=0,002)$. Pacjenci, którzy nie byli hospitalizowani w okresie ostatniego roku, byli lepiej odżywieni od chorych hospitalizowanych 2 i więcej razy $(26,59$ vs. 21,2; $p<0,001)$. U pacjentów bez powikłań stan odżywienia był lepszy. Obecność 
Tabela 6. Analiza korelacji wpływu wieku i apetytu na stan odżywienia

\begin{tabular}{lcccc} 
Badane cechy & Wspóiczynnik korelacji & $p$ & Kierunek zależności & Siła zależności \\
Wiek i stan odżywienia & $-0,26$ & 0,007 & Ujemny & Bardzo słaba \\
\hline Apetyt i stan odżywienia & 0,743 & $<0,001$ & Dodatni & Silna \\
\hline
\end{tabular}

Tabela 7. Wpływ czynników socjoklinicznych na stan odżywienia dla całej grupy

\begin{tabular}{|c|c|c|c|c|c|}
\hline \multirow{2}{*}{ Czynnik } & \multicolumn{4}{|c|}{ MNA (punkty) } & \multirow{2}{*}{$\mathbf{p}$} \\
\hline & $\mathbf{N}$ & Średnia & SD & Mediana & \\
\hline \multicolumn{5}{|c|}{ Choroby przewlekłe: } & \multirow{3}{*}{0,002} \\
\hline Nie & 52 & 23,84 & 4,95 & 25,75 & \\
\hline Tak & 56 & 21,48 & 4,43 & 21,5 & \\
\hline \multicolumn{5}{|c|}{$\begin{array}{l}\text { Hospitalizacje } \\
\text { w okresie } 12 \text { miesięcy: }\end{array}$} & \multirow{7}{*}{$<0,001$} \\
\hline 0 razy & 38 & 26,59 & 2,04 & 27 & \\
\hline Raz & 10 & 23,15 & 4,26 & 23,75 & \\
\hline 2 razy & 15 & 21,2 & 4,02 & 21 & \\
\hline 3 razy & 13 & 19,5 & 4,34 & 20,5 & \\
\hline 4 razy & 16 & 19,5 & 3,72 & 19,75 & \\
\hline 5 razy i więcej & 16 & 19,81 & 5,54 & 20,5 & \\
\hline \multicolumn{5}{|c|}{ Nudności, wymioty: } & \multirow{3}{*}{$<0,001$} \\
\hline Nie & 80 & 23,93 & 4,3 & 25 & \\
\hline Tak & 28 & 18,88 & 4,27 & 18 & \\
\hline \multicolumn{5}{|l|}{ Wyłysienie: } & \multirow{3}{*}{$<0,001$} \\
\hline Nie & 73 & 24,04 & 4,57 & 25,5 & \\
\hline Tak & 35 & 19,64 & 3,89 & 20 & \\
\hline \multicolumn{5}{|c|}{ Owrzodzenia jamy ustnej: } & \multirow{3}{*}{0,013} \\
\hline Nie & 95 & 23,02 & 4,77 & 24 & \\
\hline Tak & 13 & 19,69 & 4,25 & 20 & \\
\hline \multicolumn{5}{|l|}{ Chemioterapia: } & \multirow{3}{*}{$<0,001$} \\
\hline Nie & 70 & 24,23 & 4,35 & 25,5 & \\
\hline Tak & 38 & 19,64 & 4,21 & 20,25 & \\
\hline
\end{tabular}

MNA - Mini Nutritional Assessment

owrzodzeń jamy ustnej wiązała się z gorszym stanem odżywienia $(23,02$ vs. 19,69; $p=0,013)$, podobnie występowanie nudności i wymiotów $(23,93$ vs. 18,88; $\mathrm{p}<0,001)$ i łysienie $(24,04$ vs. 19,64; $\mathrm{p}<0,001)$. U pacjentów, u których nie stosowano chemioterapii, stan odżywienia był lepszy w porównaniu z chorymi leczonymi chemicznie (24,23 vs. 19,64; $p<0,001)$.

Spośród parametrów laboratoryjnych wykazujących istotny związek ze stanem odżywienia należy wymienić hematokryt, liczbę erytrocytów i MCV (tab. 8). Wyższy hematokryt i stężenie erytrocytów dotyczyły pacjentów lepiej odżywionych lub z prawidłowym stanem odżywienia, natomiast wyższe MCV wiązało się z gorszym stanem odżywienia. Na wynik MNA MCH i MCHC nie wykazały wpływu.

W modelu regresji liniowej wykazano, że niezależny czynnik predykcyjny stanu odżywienia stanowi apetyt ( $p<0,001)$ (tab. 9).

\section{Dyskusja}

W badaniach własnych u 13\% ankietowanych z niedokrwistością stwierdzono niedożywienie, co jest zgodne z doniesieniem Evansa, w którym wykazano, że niedożywienie dotyczy jedynie 3-12\% populacji, jednak wzrasta ono z wiekiem i czasem trwania ho- 
Tabela 8. Wpływ wartości hematokrytu na stan odżywienia dla całej grupy

\begin{tabular}{lcccc} 
Badane cechy & Współczynnik korelacji & $p$ & Kierunek zależności & Siła zależności \\
Hematokryt i stan odżywienia & 0,3 & 0,002 & Dodatni & Słaba \\
\hline Erytrocyty i stan odżywienia & 0,316 & 0,001 & Dodatni & Słaba \\
\hline MCV i stan odżywienia & $-0,203$ & 0,035 & Ujemny & Bardzo słaba \\
\hline MCH i stan odżywienia & $-0,106$ & 0,277 & - & - \\
\hline MCHC i stan odżywienia & 0,044 & 0,651 & - & - \\
\hline
\end{tabular}

Tabela 9. Analiza wieloczynnikowa wybranych zmiennych i wyników MNA

\begin{tabular}{|c|c|c|c|c|c|}
\hline \multirow{2}{*}{$\begin{array}{l}\text { Zmienna } \\
\text { Wiek (lata) }\end{array}$} & & \multirow{2}{*}{$\begin{array}{l}\text { Regresja } \\
-0,001\end{array}$} & \multicolumn{2}{|c|}{$95 \% \mathrm{Cl}$} & \multirow{2}{*}{$\begin{array}{c}p \\
0,96\end{array}$} \\
\hline & & & $-0,058$ & 0,055 & \\
\hline Apetyt (punkty) & & 0,554 & 0,334 & 0,774 & $<0,001$ \\
\hline \multirow{2}{*}{$\begin{array}{l}\text { Rodzaj } \\
\text { niedokrwistości }\end{array}$} & Z niedoboru żelaza & poz. ref. & & & \\
\hline & Aplastyczna & $-0,024$ & $-2,146$ & 2,098 & 0,982 \\
\hline \multirow[t]{2}{*}{ Płeć } & Mężczyzna & poz. ref. & & & \\
\hline & Kobieta & $-0,132$ & $-1,41$ & 1,146 & 0,838 \\
\hline \multirow[t]{2}{*}{ stan cywilny } & W związku & poz. ref. & & & \\
\hline & Wolna/y & $-0,425$ & $-1,646$ & 0,797 & 0,491 \\
\hline \multirow{2}{*}{$\begin{array}{l}\text { Miejsce } \\
\text { zamieszkania }\end{array}$} & Miasto & poz. ref. & & & \\
\hline & Wieś & 0,526 & $-0,649$ & 1,7 & 0,376 \\
\hline \multirow[t]{4}{*}{ Wykształcenie } & Podstawowe & poz. ref. & & & \\
\hline & Zawodowe & 1,534 & $-0,645$ & 3,714 & 0,165 \\
\hline & Średnie & 1,155 & $-0,959$ & 3,268 & 0,28 \\
\hline & Wyższe & $-0,746$ & $-2,907$ & 1,414 & 0,494 \\
\hline \multirow{3}{*}{$\begin{array}{l}\text { Aktywność } \\
\text { zawodowa }\end{array}$} & Czynny/a zawodowo & poz. ref. & & & \\
\hline & Bezrobotny/a & $-1,475$ & $-3,282$ & 0,333 & 0,108 \\
\hline & Emeryt/ka, rencista/ka & $-1,553$ & $-3,508$ & 0,401 & 0,118 \\
\hline \multirow{2}{*}{$\begin{array}{l}\text { Choroby } \\
\text { przewlekłe }\end{array}$} & Nie & poz. ref. & & & \\
\hline & Tak & $-0,511$ & $-2,059$ & 1,037 & 0,513 \\
\hline \multirow[t]{6}{*}{ hospitalizacje } & 0 razy & poz. ref. & & & \\
\hline & raz & $-0,42$ & $-2,886$ & 2,046 & 0,736 \\
\hline & 2 razy & $-1,338$ & $-3,622$ & 0,945 & 0,247 \\
\hline & 3 razy & $-2,637$ & $-5,327$ & 0,053 & 0,055 \\
\hline & 4 razy & $-1,164$ & $-4,057$ & 1,73 & 0,426 \\
\hline & 5 razy i więcej & $-1,005$ & $-3,889$ & 1,878 & 0,49 \\
\hline \multirow{2}{*}{$\begin{array}{l}\text { Nudności } \\
\text { wymioty }\end{array}$} & Nie & poz. ref. & & & \\
\hline & Tak & $-1,348$ & $-3,176$ & 0,48 & 0,146 \\
\hline \multirow[t]{2}{*}{ Wyłysienie } & Nie & poz. ref. & & & \\
\hline & Tak & $-0,422$ & $-2,731$ & 1,887 & 0,717 \\
\hline \multirow{2}{*}{$\begin{array}{l}\text { Owrzodzenia jamy } \\
\text { ustnej }\end{array}$} & Nie & poz. ref. & & & \\
\hline & Tak & 0,653 & $-1,35$ & 2,656 & 0,519 \\
\hline \multirow[t]{2}{*}{ Chemioterapia } & Nie & poz. ref. & & & \\
\hline & Tak & 0,508 & $-1,567$ & 2,582 & 0,628 \\
\hline
\end{tabular}


spitalizacji [6]. Problemy z apetytem mogą występować jako objawy niedokrwistości lub jej przyczyna [7]. Mniejszy apetyt zaobserwowano u 33\% ankietowanych, którzy wymagali wzmożonej obserwacji stanu odżywiania.

W analizie wieloczynnikowej stwierdzono wpływ apetytu na stan odżywiania. Utrata apetytu jest częstym czynnikiem pogorszenia stanu odżywienia prowadzącym do niedożywienia. Wpływ utraty apetytu na stan odżywienia jest szczególnie istotny u chorych hemodializowanych i w podeszłym wieku. Według Romejko-Ciepielewskiej 30\% chorych hemodializowanych jest niedożywionych z powodu utraty apetytu [8]. Antczak-Domagała i wsp. jako jeden z istotnych czynników wpływających na niedożywienie osób w podeszłym wieku podają utratę apetytu [9].

Stan odżywienia badanych osób ulegał pogorszeniu wraz z wiekiem. Niedożywienie białkowo-kaloryczne rozpoznawane jest znaczniej częściej u osób starszych, w porównaniu z osobami młodszymi, zwłaszcza wśród pacjentów zakładów opieki długoterminowej [10]. Dobry stan odżywienia zależy również od wykształcenia. Badani z wyższym wykształceniem byli znacznie lepiej odżywieni, w porównaniu z tymi z wykształceniem podstawowym. Duda i Wichura-Demska przeprowadziły badania ankietowe dotyczące wiedzy na temat zdrowego stylu życia i prawidłowego odżywiania, w którym 66\% osób z wyższym wykształceniem uzyskało bardzo dobry wynik w zakresie wiedzy na temat prawidłowego odżywiania [11].

Aktywność zawodowa również wpływa na stan odżywienia, przy czym 50\% pacjentów nieodżywionych była bezrobotnymi, natomiast $57,69 \%$ badanych z prawidłowym stanem odżywienia była czynna zawodowo. Aktywność zawodowa istotnie wpływa na stan odżywienia, osoby niedożywione częściej chorują, ich wydajność w pracy jest gorsza [12].

Pacjenci, którzy skarżyli się na nudności i wymioty byli gorzej odżywieni, przewlekłe wymioty mogą prowadzić do niedożywienia [13]. U pacjentów leczonych chemicznie stan odżywienia był gorszy. Chemioterapia stosowana jest w leczeniu nowotworów, w chwili rozpoznania niedożywienie występuje u 15-40\% chorych na nowotwory, wraz z rozwojem choroby i stosowaniem cytostatyków odsetek ten wzrasta do $80 \%$ pacjentów [14].

W badaniach laboratoryjnych krwi obwodowej zaobserwowano niższe wartości hematokrytu i liczby erytrocytów i wyższe wartości MCV, MCH, MCHC u pacjentów z niedokrwistością aplastyczną, natomiast odwrotne wyniki badania uzyskano u chorych z niedokrwistością z niedoboru żelaza, co jest zgodne z kryteriami rozpoznania i różnicowania niedokrwistości. Niedokrwistość aplastyczna należy do niedokrwistości normocytowych, normochronicznych, w których poziom MCV mieści się w zakresie 80-96 fl, poziom MCH jest również prawidłowy. Niedokrwistość z niedoboru żelaza to niedokrwistość mikrocytarna - wartość MCV spada poniżej $80 \mathrm{fl}, \mathrm{MCH}$ poniżej 29 pg, a MCHC poniżej $30 \mathrm{~g} / \mathrm{dl}$ [15-17].

Pacjenci niedożywieni i zagrożeni niedożywieniem wykazywali niższe wartości hematokrytu i liczby erytrocytów, w porównaniu z pacjentami z prawidłowym stanem odżywiania. Poziom hematokrytu i liczba erytrocytów uważane są za jeden z biochemicznych wskaźników stanu odżywiania [18]. Mitrache i wsp wykazali, że niedożywienie często współwystępuje z niedokrwistością, u 42\% pacjentów niedożywionych stwierdzono niedokrwistość [19].

Częstość i liczba hospitalizacji wpływa na stan odżywienia; 35\% pacjentów niedożywionych było hospitalizowanych 5 i więcej razy w okresie ostatniego roku, co potwierdzają przeprowadzone badania - do szpitala trafia $30-50 \%$ pacjentów niedożywionych, u 70\% dochodzi podczas hospitalizacji do nasilenia niedożywienia [20]. Pacjenci z prawidłowym staniem odżywienia w 63,46\% nie byli ani razu hospitalizowani. Pacjenci, którzy nie byli hospitalizowani w okresie ostatniego roku byli znaczniej lepiej odżywieni, w porównaniu z chorymi hospitalizowanymi 2 i więcej razy. Wynika z tego, że liczba hospitalizacji wpływa na odżywienie. Wyniki badań przeprowadzonych przez Cowan i wsp. wykazały, że $60 \%$ chorych przebywających w szpitalach jest nieodżywionych [21]. Im większa liczba powikłań po leczeniu, tym gorszy stan odżywienia, zagrożenie niedożywieniem i niedożywienie wystąpiło u 75 pacjentów z powikłaniami po leczeniu.

Gorszy stan odżywienia zaobserwowano u pacjentów ze współistniejącymi chorobami przewlekłymi. Pacjenci bez dodatkowego obciążenia chorobami przewlekłymi zazwyczaj odżywiali się prawidłowo. Wyniki te są zgodne z wieloma innymi publikacjami, choroby przewlekłe powodują dodatkowe ograniczenie w spożywaniu pokarmów i częściej dotyczą osób w podeszłym wieku [22-24]. Stan odżywienia zależy również od wystąpienia owrzodzeń jamy ustnej, które powodują nasilony ból, obrzęk błony śluzowej i suchość w jamie ustnej oraz zaburzenia odczuwania smaku. Objawy te prowadzą do niechęci i trudności w przyjmowaniu pokarmów, a w konsekwencji do zagrożenia niedożywieniem lub niedożywienia [25].

\section{Wnioski}

1. Pacjenci z niedokrwistością aplastyczną wykazują gorszy stan odżywienia, w porównaniu z chorymi z niedokrwistością z niedoboru żelaza. 
2. Apetyt stanowi niezależny czynnik predykcyjny stanu odżywienia pacjentów z rozpoznaniem niedokrwistości aplastycznej i z niedoboru żelaza.

3. Stan odżywienia zależy od wieku, wykształcenia, aktywności zawodowej, chorób współistniejących, nudności, wymiotów, owrzodzeń jamy ustnej i chemioterapii oraz liczby hospitalizacji.

\section{Piśmiennictwo}

1. Nutrition (2006). WHO, UNICEF, and SCN informa Iconsultation on community-based management of severe malnutrition in children - SCN Nutrition Policy Paper No. 21. http://www.who.int/child_adolescent_health/documents/fnbv27n3_suppl/en/index.html (05.12.2018).

2. Biernat J, Wyka J. Stan odżywienia w aspekcie stanu zdrowia. Now Lek. 2011; 80: 3.

3. Jarosz M. (red.). Otyłość, żywienie, aktywność fizyczna, zdrowie Polaków. Instytut Żywności i Żywienia, Warszawa 2006.

4. Szczygieł B. Leczenie żywieniowe. Med. Prakt. Chir. 2002; 5-6: 38-45.

5. Guigoz Y. The Mini Nutritional Assessment (MNA) review of the literature - What does it tell us? J Nutr Health Aging. 2006; 10(6): 466-85; discussion 485, indexed in Pubmed: 17183419.

6. Evans W. Protein Nutrition, Exercise and Aging. Journal of the American College of Nutrition. 2004; 23(sup6), doi: 10.1080/07315724.2004.10719430.

7. Chełstowska M, Warzocha K. Objawy kliniczne i zmiany laboratoryjne $w$ diagnostyce różnicowej niedokrwistości. Onkologia w praktyce klinicznej. 2006; 2(3): 106-107.

8. Romejko-Ciepielewska R, Niemczyk S. Anoreksja u chorych z przewleką niewydolnością nerek, wpływ czynników hormonalnych. Nefrologia i Dializoterapia Polska. 2009; 13(2): 80.

9. Antczak-Domagała R, Magierski R, Wlazło A, et al. Stan odżywienia oraz sposoby jego oceny u osób w podeszłym wieku i u chorych otępiałych. Psychiatr Psychol Klin. 2013; 13(4): 272.

10. Brennan MD, Powell C, Kaufman KR, et al. The impact of overt and subclinical hyperthyroidism on skeletal muscle. Thyroid. 2006; 16(4): 375-380, doi: 10.1089/thy.2006.16.375, indexed in Pubmed: 16646684.

11. Duda G. Wichura-Demska A. Wpływ wybranych czynników socjodemograficznych na poziom wiedzy osób zdrowych dotyczącej racjonalnego żywienia. Now Lek. 2008; 77(4): 291.

12. Grzybowski A, Grzybowski P, Mrzygłód S, et al. Żywieniowe uwarunkowania stanu zdrowia ludzi w wieku produkcyjnym w świetle norm i zwyczajów żywieniowych. Probl Hig Epidemiol. 2007; 88(1): 2.

13. Mokrowiecka A, Małecka-Panas E. Postępowanie u chorego z nudnościami i wymiotami. In: Yamada T. ed. Podręcznik gastroenterologii, wydanie polskie pod redakcją E. Małeckiej-Panas. Wydawnictwo Czelej, Lublin 2006.

14. Stasik Z, Skotnicki P, Jakubowicz J, et al. Biochemiczne wskaźniki niedożywienia u chorych na nowotwory. J Lab Diagn. 2009; 45(1): 91.

15. Szczeklik A. Choroby wewnętrzne. Medycyna Praktyczna, Kraków 2005.

16. Hellmann A, Mital A. Niedokrwistości niedoborowe - diagnostyka i leczenie. Przew Lek. 2001; 4(7): 90.

17. Orlicz-Szczęsna G, Żelazowska-Posiej J, Kucharska K. Niedokrwistość z niedoboru żelaza. Curr Probl Psychiatry. 2011; 12(4): 592.

18. Jarosz M, Charzewska J, Chabros E, Białkowska M. Metody oceny stanu odżywiania. In: Jarosz M. ed. Zasady prawidłowego żywienia chorych w szpitalach. Instytut Żywności i Żywienia, Warszawa 2011.

19. Mitrache C, Passweg JR, Libura J, et al. Anemia: an indicator for malnutrition in the elderly. Ann Hematol. 2001; 80(5): 295-298, indexed in Pubmed: 11446733.

20. Ryżko-Skiba M. Ocena stanu odżywienia chorych w wybranych szpitalach w Polsce. Rozprawa doktorska AM, Warszawa 2003.

21. Cowan DT, Roberts JD, Fitzpatrick JM, et al. Nutritional status of older people in long term care settings: current status and future directions. Int J Nurs Stud. 2004; 41(3): 225-237, doi: 10.1016/50020-7489(03)00131-7, indexed in Pubmed: 14967179.

22. Pysz-Izdebska K, Leszczyńska T, Kopeć A, et al. Pokrycie zapotrzebowania na energię i wybrane składniki odżywcze w diecie pensjonariuszy domu pomocy społecznej oraz ocena ich parametrów antropometrycznych. Żywność Nauka Technologia Jakość. 2010; 6(73): 240.

23. Gabrowska E, Spodaryk M. Społeczno-ekonomiczne uwarunkowania zachowań żywieniowych starszych mieszkańców Krakowa. Gerontol Pol. 2003; 11(1): 35-37.

24. Gabrowska E, Spodaryk M. Zasady żywienia osób w starszym wieku. Gerontol Pol. 2006; 14(2): 58.

25. Nasiłowska-Adamska B. Profilaktyka i leczenie zaburzeń przewodu pokarmowego towarzyszących chemioterapii i radioterapii, Hematologia. 2011; 2(2): 150. 